\title{
Novel series of acridone-1,2,3-triazole derivatives: microwave-assisted synthesis, DFT study and antibacterial activities
}

\author{
MOHAMMED AARJANE ${ }^{\mathrm{a}}$, SIHAM SLASSI ${ }^{\mathrm{a}}$, BOUCHRA TAZI $^{\mathrm{b}}$, MOHAMED MAOULOUA $^{\mathrm{c}}$ \\ and AMINA AMINE ${ }^{\mathrm{a}, *(D)}$ \\ ${ }^{a}$ LCBAE, CMMBA, Faculty of Science, University Moulay Ismail, BP 11201, Zitoune, Meknes, Morocco \\ ${ }^{b}$ Département des Sciences de Base, Ecole Nationale d'Agriculture, Meknes, Morocco \\ ${ }^{\mathrm{c}}$ Medical Microbiology Laboratory, Mohamed V. Hospital, Meknes, Morocco \\ E-mail: amine_7a@yahoo.fr
}

MS received 4 April 2019; revised 27 May 2019; accepted 28 May 2019

\begin{abstract}
A series of novel acridones bearing a 1,2,3-triazole unit have been synthesized and characterized. The copper(I)-catalyzed azide-alkyne cycloaddition (CuAAC) was performed using both a conventional method and a microwave-assisted synthetic method. The in vitro antibacterial potencies of all the synthesized compounds were determined against five clinically isolated strains: Escherichia coli, Klebsiella pneumonia, Pseudomonas putida, Serratia marcescens and Staphyloccocus aureus. Furthermore, DFT quantum chemical calculations were carried out to investigate geometry structures, frontier molecular orbital and gap energies, and molecular electrostatic potential maps (MEP). Lipophilicities of the studied compounds were also determined.
\end{abstract}

Keywords. Acridone; 1, 2, 3-triazole; microwave; DFT study; antibacterial activitiy.

\section{Introduction}

Acridones are heterocyclic compounds with important biological activities. ${ }^{1}$ Acronycine was the first acridone alkaloid that has been isolated from an Acronychia baueri Schott plant, ${ }^{2}$ and which displayed a broad-spectrum activity against a variety of experimental tumor models. ${ }^{3,4}$ Due to their planar ring, these molecules could intercalate between nucleotide base pairs in the helix of the cancer cell DNA. ${ }^{5-7}$ Many Acridone derivatives such as nitracrine, amsacrine, DACA and asulacrine ${ }^{8-10}$ are used clinically or are under clinical observations. Moreover, exhaustive research has been conducted on acridine and acridone derivatives showing anti-cancer, ${ }^{11}$ antitumor, ${ }^{12}$ antiviral, ${ }^{13}$ antimalarial, ${ }^{14}$ antimicrobial ${ }^{15}$ and anti-inflammatory ${ }^{16}$ bioactivities.

On the other hand, 1,2,3-triazole and its derivatives are an important class of heterocycles, that attract the attention of organic chemists ${ }^{17}$ due to their significant pharmacological potential ${ }^{18}$ and a broad spectrum of applications in biochemical and medicinal chemistry such as anti-HIV, ${ }^{19}$ antimicrobial, ${ }^{20}$ antioxidant, ${ }^{21}$ anticancer, ${ }^{22}$ and acetylcholinesterase and butyrylcholinesterase inhibitory ${ }^{23}$ activities. Click reaction is the most popular method for the construction of 1,2,3-triazoles. This synthetic method, introduced by Sharpless, ${ }^{24}$ is an important topic in organic synthesis since it constitutes a powerful bond forming reaction with many applications including different fields from materials science to drug discovery. ${ }^{25}$ The copper(I)-catalyzed azide-alkyne cycloaddition (CuAAC) makes the reaction quantitative and selective for the synthesis of 1,4-disubstituted 1,2,3triazole and decreases the completion reaction time. ${ }^{26,27}$

Considering the many adverse effects and development of antimicrobial resistance, ${ }^{28}$ there is a big demand for novel and efficient antimicrobial agents. ${ }^{29}$ Inspired with the biological profile of acridone and 1,2,3-triazoles and their increasing importance in pharmaceutical fields, we have synthesized novel acridon1,2,3-triazole compounds using the copper(I)-catalyzed azide-alkyne cycloaddition (CuAAC) to obtain novel

\footnotetext{
*For correspondence

Electronic supplementary material: The online version of this article (https://doi.org/10.1007/s12039-019-1653-2) contains supplementary material, which is available to authorized users.
} 
drugs with antibacterial potential. The new molecules were prepared under microwave irradiations conditions then tested against five clinically isolated bacterial strains.

Additionally, a theoretical study using DFT quantum chemical calculations was carried out in order to explore the electronic properties of the synthesized compounds. Hence, optimized geometry structures, frontier molecular orbital and gap energies, molecular electrostatic potential maps (MEP) were investigated. Lipophilicities were determined to help understand the relationship between structure and biological activities of our compounds.

\section{Experimental}

\subsection{Materials}

All materials were purchased from commercial suppliers. Infrared spectra were recorded using a JASCO FT-IR 4100 spectrophotometer. The ${ }^{1} \mathrm{H}$ and ${ }^{13} \mathrm{C}$ NMR spectra were recorded with a Bruker Avance 300 at $25^{\circ} \mathrm{C}$. Mass spectrometric measurements were recorded using SHIMADZU 8040 LC/MS/MS. Microwave irradiation was carried out with CEM Discover $^{\mathrm{TM}}$.

\subsection{Synthesis}

General procedure for the synthesis of acridon-1,2,3triazole derivatives $(4 a-h)$ Conventional procedure: A mixture of 10-(prop-2-yn-1-yl)acridone $(0.1 \mathrm{~g}, 0.42 \mathrm{mmol}$ ), 2-azido- $\mathrm{N}$-phenylacetamide $(0.11 \mathrm{~g}, 0.63 \mathrm{mmol})$, copper sulfate $(20 \mathrm{mg}, 0.08 \mathrm{mmol})$ and sodium ascorbate $(33 \mathrm{mg}, 0.16$ $\mathrm{mmol})$ in DMF $(5 \mathrm{~mL})$ was stirred at room temperature for 10 h. After completion of the reaction (monitored by TLC), the mixture was diluted with water, poured onto ice, and the precipitate was filtered off, washed with cold water, and purified by flash chromatography on silica gel using hexane/diethyl ether to afford desire product.

Microwave-assisted procedure: A mixture of 10-(prop-2yn-1-yl)acridone $(0.1 \mathrm{~g}, 0.42 \mathrm{mmol})$, copper sulfate $(20 \mathrm{mg}$, $0.08 \mathrm{mmol}$ ) and sodium ascorbate $(33 \mathrm{mg}, 0.16 \mathrm{mmol}$ ) were suspended in $5 \mathrm{~mL}$ of solvent in a glass vial equipped with a small magnetic stirring bar. To this, 2-azido-Nphenylacetamide $(0.11 \mathrm{~g}, 0.63 \mathrm{mmol})$ was added and the vial was tightly sealed. The mixture was then irradiated for 10 min at a fixed temperature $\left(40-100^{\circ} \mathrm{C}\right)$. Microwave irradiation power was set at $200 \mathrm{~W}$ maximum. After completion of the reaction, the vial was cooled and the reaction mixture poured into ice cold water, and purified by flash chromatography on silica gel using hexane/diethyl ether to afford desire product.

2-(4-((9-oxoacridin-10(9H)-yl)methyl)-1H-1,2,3-triazol-1yl)-N-phenylacetamide (4a).
Yellow solid; yield: $81 \%$, M.p. $>300^{\circ} \mathrm{C}$. IR (KBr): 3266, 3088, 2985, 1703, 1630, 1614, 1598, 1563, $1499 \mathrm{~cm}^{-1}$. ${ }^{1} \mathrm{HNMR}\left(300 \mathrm{MHz},\left[\mathrm{D}_{6}\right] \mathrm{DMSO}, 25^{\circ} \mathrm{C}\right.$, TMS): $\delta 10.40$ $(\mathrm{s}, 1 \mathrm{H}, \mathrm{NH}), 8.36(\mathrm{dd}, J=8.0,1.7 \mathrm{~Hz}, 2 \mathrm{H}, \mathrm{H} 1-\mathrm{H} 8)$, $8.16(\mathrm{~s}, 1 \mathrm{H}$, triazole $), 7.98(\mathrm{~d}, J=8.8 \mathrm{~Hz}, 2 \mathrm{H}, \mathrm{H} 4$, H5), 7.82 (td, $J=8.8,6.9,1.8 \mathrm{~Hz}, 2 \mathrm{H}, \mathrm{H} 3, \mathrm{H} 6), 7.51$ $\left(\mathrm{d}, J=7.8 \mathrm{~Hz}, 2 \mathrm{H}, \mathrm{H1}^{\prime}, \mathrm{H}^{\prime}\right), 7.32(\mathrm{~m}, 4 \mathrm{H}), 7.04(\mathrm{t}, 1 \mathrm{H}$, $\mathrm{H}^{\prime}$ ), 5.84 (s, 2H, CH2), 5.27 (s, 2H, CH2); ${ }^{13} \mathrm{C}$ NMR (75 $\mathrm{MHz},\left[\mathrm{D}_{6}\right.$ ]DMSO, $25^{\circ} \mathrm{C}$, TMS): $177.06,164.52,142.72$, $142.25,138.81,134.66,129.34,127.12,125.49,124.21$, 122.18, 121.99, 119.65, 116.82, 52.69, 41.97. MS (ESI) for $\mathrm{C}_{24} \mathrm{H}_{19} \mathrm{~N}_{5} \mathrm{O}_{2}[\mathrm{M}+1]^{+}$, calcd: 410.45 , found: 410.44 .

2-(4-((9-oxoacridin-10(9H)-yl)methyl)-1H-1,2,3-triazol-1yl)-N-(p-tolyl)acetamide (4b).

Yellow solid; yield: $84 \%$, M.p. $>300^{\circ} \mathrm{C}$. IR (KBr): 3267 , 3078, 2935, 1704, 1629, 1616, 1594, $1555 \mathrm{Cm}^{-1} .{ }^{1} \mathrm{HNMR}$ (300 MHz, [D 6 ]DMSO, $\left.25^{\circ} \mathrm{C}, \mathrm{TMS}\right): \delta 10.31(\mathrm{~s}, 1 \mathrm{H}, \mathrm{NH})$, $8.35(\mathrm{dd}, J=8.0,1.7 \mathrm{~Hz}, 2 \mathrm{H}), 8.15(\mathrm{~s}, 1 \mathrm{H}), 7.98(\mathrm{~d}$, $J=8.8 \mathrm{~Hz}, 2 \mathrm{H}), 7.82(\mathrm{td}, J=8.8,6.9,1.8 \mathrm{~Hz}, 2 \mathrm{H}), 7.45-$ $7.28(\mathrm{~m}, 4 \mathrm{H}), 7.1(\mathrm{~d}, J=8.0 \mathrm{~Hz}, 2 \mathrm{H}), 5.83(\mathrm{~s}, 2 \mathrm{H}, \mathrm{CH} 2)$, 5.24 (s, 2H, CH2), 2.22 (s, 3H, CH3); ${ }^{13} \mathrm{C}$ NMR $(75 \mathrm{MHz}$, $\left[\mathrm{D}_{6}\right] \mathrm{DMSO}, 25^{\circ} \mathrm{C}$, TMS) $\delta 177.06,164.25,142.69,142.25$, $136.30,134.66,133.19$, 129.70, 127.12, 125.47, 122.18, 121.99, 119.64, 116.82, 52.66, 41.96, 20.89. MS (ESI) for $\mathrm{C}_{25} \mathrm{H}_{21} \mathrm{~N}_{5} \mathrm{O}_{2}[\mathrm{M}+1]^{+}$, calcd: 424.47 , found: 424.29 .

2-(4-((9-oxoacridin-10(9H)-yl)methyl)-1H-1,2,3-triazol-1yl)-N-(o-tolyl)acetamide (4c).

Yellow solid; yield: $88 \%$, M.p. $>300^{\circ} \mathrm{C}$. IR (KBr): 3260 , 3121, 3064, 2936, 1670, 1630, 1600, 1542, $1495 \mathrm{~cm}^{-1}$. ${ }^{1} \mathrm{HNMR}\left(300 \mathrm{MHz},\left[\mathrm{D}_{6}\right] \mathrm{DMSO}, 25^{\circ} \mathrm{C}, \mathrm{TMS}\right): \delta 9.76(\mathrm{~s}, 1 \mathrm{H}$, $\mathrm{NH}), 8.36(\mathrm{~d}, J=7.8 \mathrm{~Hz}, 2 \mathrm{H}, \mathrm{H} 1-\mathrm{H} 8), 8.19(\mathrm{~s}, 1 \mathrm{H}$, triazole), 7.99 (d, $J=8.7 \mathrm{~Hz}, 2 \mathrm{H}, \mathrm{H} 4, \mathrm{H} 5), 7.83$ (t, $J=7.8 \mathrm{~Hz}$, $2 \mathrm{H}, \mathrm{H} 3, \mathrm{H} 6), 7.36(\mathrm{~m}, 3 \mathrm{H}), 7.15(\mathrm{~m}, 3 \mathrm{H}), 5.85$ (s, 2H, CH2), 5.34 (s, 2H, CH2), 2.16 (s, 3H, CH3); ${ }^{13} \mathrm{C}$ NMR (75 MHz, $\left[\mathrm{D}_{6}\right.$ ]DMSO, $25^{\circ} \mathrm{C}$, TMS) $\delta 177.08,164.76,142.77,142.24$, $135.91,134.68,133.94,132.00,130.88,127.13,126.15$, 126.01, 125.5, 122.17, 121.48, 117.81, 52.44, 41.95, 18.22 . MS (ESI) for $\mathrm{C}_{25} \mathrm{H}_{21} \mathrm{~N}_{5} \mathrm{O}_{2}[\mathrm{M}+1]^{+}$, calcd: 424.47 , found: 424.32 .

\section{2-(2-(4-((9-oxoacridin-10(9H)-yl)methyl)-1H-1,2,3- triazol-1-yl)acetamido)benzoic acid (4d).}

Yellow solid; yield: $73 \%$, M.p. $>300^{\circ} \mathrm{C}$. IR (KBr): 3401 , 3240, 2933, 2842, 1700, 1630, 1612, 1597, $1475 \mathrm{~cm}^{-1}$. ${ }^{1} \mathrm{HNMR}\left(300 \mathrm{MHz},\left[\mathrm{D}_{6}\right] \mathrm{DMSO}, 25^{\circ} \mathrm{C}\right.$, TMS): $\delta 11.57$ (br s, $1 \mathrm{H}, \mathrm{OH}), 10.19$ (s, 1H, NH), 8.60 (d, $J=8.5 \mathrm{~Hz}, 1 \mathrm{H}, \mathrm{H} 2$ '), $8.36(\mathrm{dd}, J=8.0,1.7 \mathrm{~Hz}, 2 \mathrm{H}, \mathrm{H} 1-\mathrm{H} 8), 8.15(\mathrm{~s}, 1 \mathrm{H}$, triazole), $8.01(\mathrm{~d}, J=8.8 \mathrm{~Hz}, 2 \mathrm{H}, \mathrm{H} 4, \mathrm{H} 5), 7.69-7.61(\mathrm{~m}$, $5 \mathrm{H}, \mathrm{Ar}-\mathrm{H}), 7.34-7.26(\mathrm{~m}, 2 \mathrm{H}, \mathrm{Ar}-\mathrm{H}), 5.83$ (s, 2H, CH2), 5.28 (s, 2H, CH2); ${ }^{13} \mathrm{C}$ NMR (75 MHz, $\left[\mathrm{D}_{6}\right] \mathrm{DMSO}, 25^{\circ} \mathrm{C}$, TMS): $177.82,171.59,164.31,140.88,140.62,139.29,133.29$, $129.98,129.71,128.88,125.97,125.17,123.11,122.85$, $121.61,120.86,120.49,117.27,115.77,115.43,115.39$, 52.68, 41.96. MS (ESI) for $\mathrm{C}_{25} \mathrm{H}_{19} \mathrm{~N}_{5} \mathrm{O}_{4}[\mathrm{M}+1]^{+}$, calcd: 454.45, found: 454.40 . 
2-(4-((2-methyl-9-oxoacridin-10(9H)-yl)methyl)-1H-1,2, 3-triazol-1-yl)-N-phenylacetamide (4e).

Yellow solid; yield: $80 \%$, M.p. $>300^{\circ} \mathrm{C}$. IR (KBr): 3263 , 3137, 3085, 2926, 1703, 1632, 1618, 1592, $1498 \mathrm{~cm}^{-1}$. ${ }^{1} \mathrm{HNMR}\left(300 \mathrm{MHz},\left[\mathrm{D}_{6}\right] \mathrm{DMSO}, 25^{\circ} \mathrm{C}\right.$, TMS): $\delta 10.59(\mathrm{~s}$, $1 \mathrm{H}, \mathrm{NH}), 8.38(\mathrm{~d}, J=8.1 \mathrm{~Hz}, 1 \mathrm{H}, \mathrm{H} 1), 8.16(\mathrm{~s}, 1 \mathrm{H}, \mathrm{H} 8)$, 8.15 (s, $1 \mathrm{H}$, triazole), $7.96(\mathrm{~d}, J=8.7 \mathrm{~Hz}, 1 \mathrm{H}, \mathrm{H} 4), 7.90$ (d, $J=9 \mathrm{~Hz}, 1 \mathrm{H}, \mathrm{H} 5), 7.81(\mathrm{td}, J=8.8,6.9,1.8 \mathrm{~Hz}, 1 \mathrm{H}, \mathrm{H} 3)$, $7.68(\mathrm{dd}, J=9,2 \mathrm{~Hz}, 1 \mathrm{H}, \mathrm{H} 6) 7.56(\mathrm{~d}, J=7.5 \mathrm{~Hz}, 2 \mathrm{H}$, H1', H5'), 7.34 (m, 3H), 7.07 (t, 1H, H3'), 5.83 (s, 2H, CH2), 5.28 (s, 2H, CH2), 2.43 (s, 3H, CH3); ${ }^{13} \mathrm{C}$ NMR $(75 \mathrm{MHz}$, $\left[\mathrm{D}_{6}\right] \mathrm{DMSO}, 25^{\circ} \mathrm{C}$, TMS) $\delta 176.90,164.56,142.08,140.35$, $138.83,135.98,134.49,131.22,129.36,127.15,126.34$, $124.22,122.09,121.72,119.63,119.53,116.85,116.67$, 52.66, 41.83, 20.67. MS (ESI) for $\mathrm{C}_{25} \mathrm{H}_{21} \mathrm{~N}_{5} \mathrm{O}_{2}[\mathrm{M}+1]^{+}$, calcd: 424.16 , found: 424.04 .

2-(4-((2-methyl-9-oxoacridin-10(9H)-yl)methyl)-1H-1,2, 3-triazol-1-yl)-N-(p-tolyl)acetamide (4f).

Yellow solid; yield: $75 \%$, M.p. $>300^{\circ} \mathrm{C}$. IR (KBr): 3277 , $3124,3079,2910,1705,1632,1616,1594,1499 \mathrm{~cm}^{-1}$. ${ }^{1} \mathrm{HNMR}\left(300 \mathrm{MHz},\left[\mathrm{D}_{6}\right] \mathrm{DMSO}, 25^{\circ} \mathrm{C}\right.$, TMS): $\delta 10.30(\mathrm{~s}$, $1 \mathrm{H}, \mathrm{NH}), 8.34(\mathrm{dd}, J=8.0,1.7 \mathrm{~Hz}, 1 \mathrm{H}, \mathrm{H} 1), 8.14(\mathrm{~s}, 1 \mathrm{H}$, H8), $8.10(\mathrm{~s}, 1 \mathrm{H}$, triazole), $7.92(\mathrm{dd}, J=19.2,8.8 \mathrm{~Hz}, 2 \mathrm{H}$, H4-H5), 7.79 (td, $J=8.7,6.9,1.8 \mathrm{~Hz}, 1 \mathrm{H}, \mathrm{H} 3), 7.64$ (dd, $J=8.9,2.3 \mathrm{~Hz}, 1 \mathrm{H}, \mathrm{H} 6), 7.48-7.35(\mathrm{~m}, 2 \mathrm{H}), 7.31$ (td, $J=7.8,6.9,0.8 \mathrm{~Hz}, 1 \mathrm{H}, \mathrm{H} 2), 7.09(\mathrm{~d}, J=8.2 \mathrm{~Hz}, 2 \mathrm{H}$, H2'-H4'), 5.81 (s, 2H,CH2), 5.23 (s, 2H,CH2), 2.42 (s, 3H, $\mathrm{CH} 3$ ), 2.22 (s, $3 \mathrm{H}, \mathrm{CH} 3) ;{ }^{13} \mathrm{C}$ NMR $\left(75 \mathrm{MHz},\left[\mathrm{D}_{6}\right] \mathrm{DMSO}\right.$, $25^{\circ} \mathrm{C}$, TMS): $176.88,164.25,142.78,142.08,140.36,136.30$, $135.96,134.46,133.19,131.20,129.70,127.13,126.33$, $125.41,122.07,121.70,119.64,116.84,116.65,52.64,41.84$, 20.88, 20.66. MS (ESI) for $\mathrm{C}_{26} \mathrm{H}_{23} \mathrm{~N}_{5} \mathrm{O}_{2}[\mathrm{M}+1]^{+}$, calcd: 438.50, found: 438;36.

\section{2-(4-((2-methyl-9-oxoacridin-10(9H)-yl)methyl)-1H-1,2, 3-triazol-1-yl)-N-(o-tolyl)acetamide (4g).}

Yellow solid; yield: $88 \%$, M.p. $>300^{\circ} \mathrm{C}$. IR (KBr): 3275 , 3127, 3072, 2917, 1701, 1630, 1615, 1590, $1509 \mathrm{~cm}^{-1}$. ${ }^{1} \mathrm{HNMR}\left(300 \mathrm{MHz},\left[\mathrm{D}_{6}\right] \mathrm{DMSO}, 25^{\circ} \mathrm{C}\right.$, TMS): $\delta 0.36(\mathrm{~s}, 1 \mathrm{H}$, $\mathrm{NH}), 8.38(\mathrm{dd}, J=8.0,1.7 \mathrm{~Hz}, 1 \mathrm{H}, 1 \mathrm{H}), 8.18(\mathrm{~s}, 1 \mathrm{H}, \mathrm{H} 8)$, $8.10(\mathrm{~s}, 1 \mathrm{H}$, triazole), $7.96(\mathrm{dd}, J=19.1,8.9 \mathrm{~Hz}, 2 \mathrm{H}, \mathrm{H} 4-\mathrm{H} 5)$, $7.83(\mathrm{td}, J=8.7,6.9,1.8 \mathrm{~Hz}, 1 \mathrm{H}, \mathrm{H} 3), 7.68(\mathrm{dd}, J=8.9,2.3$ $\mathrm{Hz}, 1 \mathrm{H}, \mathrm{H} 6), 7.56-7.29(\mathrm{~m}, 3 \mathrm{H}), 7.12(\mathrm{~d}, J=8.2 \mathrm{~Hz}, 2 \mathrm{H}, \mathrm{H} 2-$ H4'), 5.85 (s, 2H, CH2), 5.26 (s, 2H, CH2), 2.45 (s, 3H, CH3), 2.25 (s, 3H, CH3); ${ }^{13} \mathrm{C}$ NMR $\left(75 \mathrm{MHz},\left[\mathrm{D}_{6}\right] \mathrm{DMSO}, 25{ }^{\circ} \mathrm{C}\right.$, TMS) $\delta 176.41,163.75,141.59,139.87,135.78,135.50$, $133.99,132.72,130.73,129.21,126.64,125.83,121.57$, 121.23, 119.17, 116.34, 116.16, 52.15, 41.36, 20.39, 20.18. MS (ESI) for $\mathrm{C}_{26} \mathrm{H}_{23} \mathrm{~N}_{5} \mathrm{O}_{2}[\mathrm{M}+1]^{+}$, calcd: 438.50 , found: 438.41 .

\section{2-(2-(4-((2-methyl-9-oxoacridin-10(9H)-yl)methyl)-1H-1, 2,3-triazol-1-yl)acetamido)benzoic acid (4h).}

Yellow solid; yield: $76 \%$, M.p. $>300^{\circ} \mathrm{C}$. IR (KBr): 3401 , 3240, 2933, 2842, 1700, 1630,1612, 1597, $1475 \mathrm{~cm}^{-1} .{ }^{1} \mathrm{H}$ NMR (300 MHz, [D $\mathrm{D}_{6}$ DMSO, $\left.25^{\circ} \mathrm{C}, \mathrm{TMS}\right): \delta 11.57$ (br s, $1 \mathrm{H}$,
OH), 10.58 (s, 1H, NH), 8.60 (d, $J=8.5 \mathrm{~Hz}, 1 \mathrm{H}, \mathrm{H} 2$ '), 8.39 (d, $J=8.1 \mathrm{~Hz}, 1 \mathrm{H}, \mathrm{H} 1), 8.27$ (d, $\left.J=8.5 \mathrm{~Hz}, 1 \mathrm{H}, \mathrm{H} 5^{\prime}\right), 8.18$ $(\mathrm{s}, 1 \mathrm{H}, \mathrm{H} 8), 8.15(\mathrm{~s}, 1 \mathrm{H}$, triazole $), 7.96(\mathrm{~d}, J=8.7 \mathrm{~Hz}, 1 \mathrm{H}, \mathrm{H} 4)$, 7.90 (d, $J=9 \mathrm{~Hz}, 1 \mathrm{H}, \mathrm{H} 5), 7.69-7.61(\mathrm{~m}, 3 \mathrm{H}, \mathrm{Ar}-\mathrm{H}), 7.31-$ 7.26 (m, 2H, Ar-H), 5.80 (s, 2H, CH2), 5.27 (s, 2H, CH2), 2.44 (s, 3H, CH3); ${ }^{13} \mathrm{C}$ NMR $\left(75 \mathrm{MHz},\left[\mathrm{D}_{6}\right] \mathrm{DMSO}, 25^{\circ} \mathrm{C}\right.$, TMS):176.80,171.60,164.38,140.98,140.32,139.00, 133.66, $129.33,129.11,128.69,125.12,124.97,122.99,121.85$, $121.69,120.77,120.19,117.55,115.37,115.39,52.65,41.86$, 20.60. MS (ESI) for $\mathrm{C}_{26} \mathrm{H}_{21} \mathrm{~N}_{5} \mathrm{O}_{4}[\mathrm{M}+1]^{+}$, calcd: 468.48, found: 468.26 .

\section{Results and Discussion}

\subsection{Chemistry}

In this work, the synthesis of acridone 1,2,3-triazole hybrid derivatives entails a three steps pathway (Scheme 1). The synthetic strategy started from the preparation of 10-(prop-2-yn-1-yl)acridone (1) as the terminal alkyne component by the substitution reaction of acridone with propargyl bromide, using $\mathrm{NaH}$ in dimethylformamide (DMF) at $80^{\circ} \mathrm{C}$. In the second setup, 2-azido- $\mathrm{N}$-phenylacetamide derivatives are prepared by reacting aniline derivatives (1.0 equiv.) and chloroacetyl chloride (1.5 equiv.) in $\mathrm{K}_{2} \mathrm{CO}_{3} / \mathrm{CH}_{2} \mathrm{Cl}_{2}$ at $0{ }^{\circ} \mathrm{C}$ to give 2-chloroN-phenylacetamide (2). The crude amide (2) was then reacted with sodium azide in DMF as solvent under moderate heat to give 2azido-N-phenylacetamide (3). The last step was the click reaction, where the 10-(prop-2-yn-1-yl)acridone undergoes a 1,3-dipolar cycloaddition with 2-azido-Nphenylacetamide (3) in the presence of copper sulfate and sodium ascorbate leading to the 1,4-disubstituted regioisomer (4).

Along with the conventional method, the assisted microwave irradiation was also employed for the 1,3dipolar cycloaddition reaction. A number of variables including solvent, copper catalyst, reducing agent and time were examined in the reaction of 10-(prop-2yn-1-yl)acridone (1a) and 2-azido-N-phenylacetamide (3a) for the optimization of the click reaction. The obtained results are summarized in (Table 1). Based on previous studies, the model click reaction was performed in water:tBuOH $(1: 1)$ as a solvent and $\mathrm{CuSO}_{4} .5 \mathrm{H}_{2} \mathrm{O} / \mathrm{NaAsc}$ as a catalytic system at room temperature, ${ }^{30}$ the expected product (4a) was obtained in $55 \%$ yield with conventional method and $60 \%$ yield with microwave irradiation. In an attempt to increase the yield of the cycloaddition reaction, we have tested other solvents (DMF, DMF/ $\mathrm{H}_{2} \mathrm{O}$, and $\mathrm{CH}_{2} \mathrm{Cl}_{2}$ ). An interesting increase in the yield of (4a) was observed in DMF, affording $73 \%$ yield after $10 \mathrm{~h}$ stirring at 
<smiles></smiles><smiles>C#CCC(C)CBr</smiles><smiles>C#CCn1c2ccccc2c(=O)c2ccccc21</smiles>

(1)<smiles>[R]c1ccc(N)cc1</smiles><smiles>[R]c1cc(NC(=O)CCl)ccc1OCCOC</smiles>

(2)<smiles>[R20]c1ccc(NC(=O)CN)cc1</smiles>

(3)

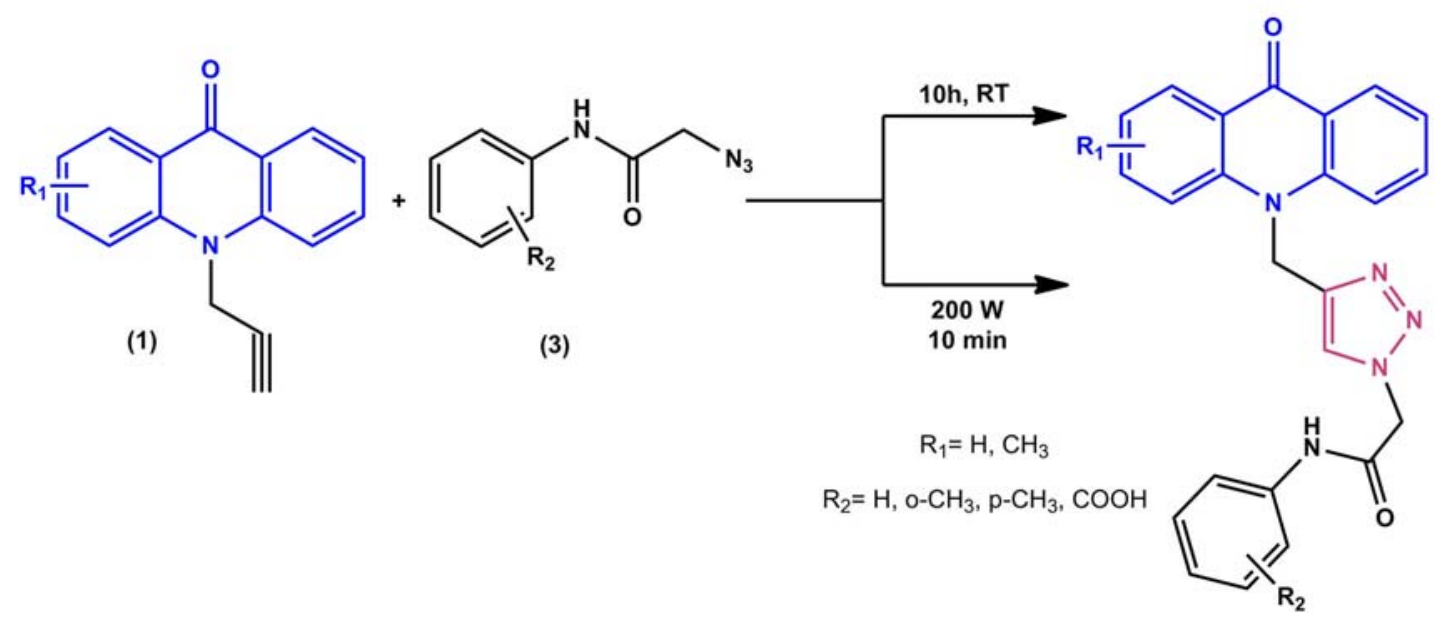

Scheme 1. The synthetic route of title compounds $(4 a-h)$.

room temperature whereas a decrease in the yield was observed when water was added as a co-solvent. This is probably due to the low solubility of 10-(prop-2-yn-1yl)acridone (1a) in aqueous media. Any change in the amount of copper catalyst and sodium ascorbate, even at reflux, was not efficient compared to optimized conditions. In order to increase the efficiency of the reaction, we used copper iodide as a source of copper and triethylamine as a protective agent. As shown in Table 1, the use of $\mathrm{CuI}$ in DMF as solvent gives moderate yield $(60 \%)$.

By the protocol of entry 3 in Table 1, novel acridone 1,2,3-triazole derivatives were synthesized with both microwave-assisted procedure and conventional method. By using MWI, the target compounds were synthesized in 10 min with excellent overall yields of 86-69\% (Table 2). Whereas with the conventional procedure, the overall yields were in the range of $60-75 \%$ and it took more than $10 \mathrm{~h}$ to complete the reaction.
Structures of novel acridon-1,2,3-triazole derivatives were characterized by IR, ${ }^{1} \mathrm{H} N M R,{ }^{13} \mathrm{C}$ NMR. The IR spectra of the novel acridon-1,2,3-triazole compounds $(4 \mathrm{a}-\mathrm{h})$ showed characteristic absorption band at $1630 \mathrm{~cm}^{-1}$ corresponding to a conjugated ketone $(\mathrm{C}=\mathrm{O})$ of the acridone ring and absorption bands in the region of $1704-1670 \mathrm{~cm}^{-1}$ corresponding to $(\mathrm{C}=\mathrm{O})$ of the amide group.

${ }^{1} \mathrm{H}$ NMR spectra of compounds $4 \mathrm{a}-\mathrm{h}$ showed a singlet for NH proton at around 10.59-9.76 ppm and another singlet for triazole proton in the range of 8.19$8.10 \mathrm{ppm}$. Aromatic protons of acridone ring and Nphenylacetamide group are visible between 8.38-7.10 ppm, while the methyl proton of substituted acridone appear at $2.45 \mathrm{ppm}$. The $\mathrm{N}-\mathrm{CH} 2$ attached to the acridone ring and $\mathrm{N}-\mathrm{CH} 2$ attached to the amide group protons resonate at around 5.84-5.27 ppm. The substituted Nphenylacetamide group yielded an intense singlet at around 2.25-2.16 ppm corresponding to the methyl 
Table 1. Optimization of reaction condition $4 \mathrm{a}^{\mathrm{a}}$

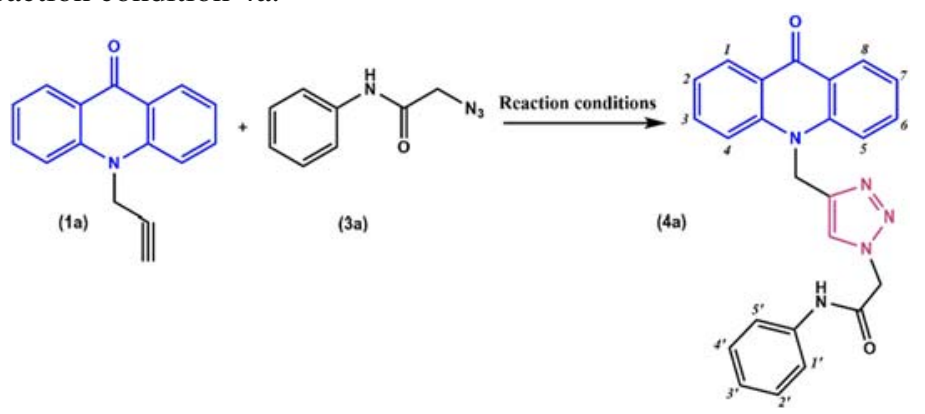

\begin{tabular}{|c|c|c|c|c|c|c|c|}
\hline \multirow[b]{2}{*}{ Entry } & \multirow[b]{2}{*}{ Copper salt } & \multirow[b]{2}{*}{ Reducing agent } & \multirow[b]{2}{*}{ Solvent (1:1) } & \multicolumn{2}{|l|}{ Time } & \multicolumn{2}{|c|}{ Yield $(\%)^{\mathrm{d}}$} \\
\hline & & & & NO-MW & $M^{f}$ & NO-MW & $\mathrm{MW}^{\mathrm{t}}$ \\
\hline 1 & $\mathrm{CuSO}_{4} .5 \mathrm{H}_{2} \mathrm{O}$ & $\mathrm{NaAsc}$ & $\mathrm{t}-\mathrm{BuOH} / \mathrm{H}_{2} \mathrm{O}$ & $24 \mathrm{~h}$ & $15 \mathrm{~min}$ & 55 & 60 \\
\hline 2 & $\mathrm{CuSO}_{4} .5 \mathrm{H}_{2} \mathrm{O}$ & $\mathrm{NaAsc}$ & $\mathrm{t}-\mathrm{BuOH}$ & $24 \mathrm{~h}$ & $15 \mathrm{~min}$ & 55 & 60 \\
\hline 3 & $\mathrm{CuSO}_{4} .5 \mathrm{H}_{2} \mathrm{O}$ & $\mathrm{NaAsc}$ & DMF & $10 \mathrm{~h}$ & $10 \mathrm{~min}$ & 73 & 81 \\
\hline 4 & $\mathrm{CuSO}_{4} .5 \mathrm{H}_{2} \mathrm{O}$ & $\mathrm{NaAsc}$ & $\mathrm{DMF} / \mathrm{H}_{2} \mathrm{O}$ & $24 \mathrm{~h}$ & $15 \mathrm{~min}$ & 61 & 72 \\
\hline 5 & $\mathrm{CuSO}_{4} .5 \mathrm{H}_{2} \mathrm{O}$ & $\mathrm{NaAsc}$ & $\mathrm{CH}_{2} \mathrm{Cl}_{2}$ & $24 \mathrm{~h}$ & $15 \mathrm{~min}$ & 68 & 71 \\
\hline $6^{\mathrm{c}}$ & $\mathrm{CuSO}_{4} .5 \mathrm{H}_{2} \mathrm{O}$ & $\mathrm{NaAsc}$ & DMF & $4 \mathrm{~h}$ & - & 69 & - \\
\hline $7^{\mathrm{b}}$ & $\mathrm{CuI}$ & - & DMF & $24 \mathrm{~h}$ & $10 \mathrm{~min}$ & 60 & 63 \\
\hline
\end{tabular}

a Reaction conditions: 3a $(1.2 \mathrm{mmol}), 1 \mathrm{a}(1 \mathrm{mmol})$, Copper salt $(20 \mathrm{~mol} \%)$, sodium ascorbate $(50 \mathrm{~mol} \%)$, solvent $(5 \mathrm{~mL})$ at room temperature. ${ }^{\mathrm{b}} 0.5 \mathrm{eq} \mathrm{Et}{ }_{3} \mathrm{~N}$. ${ }^{\mathrm{c}}$ Reflux. ${ }^{\mathrm{d}}$ Isolated yield. ${ }^{\mathrm{f}}$ Microwave conditions, $200 \mathrm{~W}$ maximum.

group, while the acid proton appear at $11.57 \mathrm{ppm}$. In the ${ }^{13} \mathrm{C}$ NMR spectrum, the chemical shifts of the carbonyls of the acridone ring and $\mathrm{CONH}$ groups of the $\mathrm{N}$-phenylacetamide resonate at around 177.8-176.4 and 164.7-163.7 ppm, respectively and another signal corresponding to the carbon of acid group are resonate at 171.5. Tow signals at a range of $63.0-54.0 \mathrm{ppm}$ corresponding to $\mathrm{N}-\mathrm{CH} 2$ attached to the acridone ring and $\mathrm{N}-\mathrm{CH} 2$ attached to the amide group protons confirmed by DEPT 135 . The signal at around $125.4-142.7 \mathrm{ppm}$ corresponding to the aromatic carbons of triazole ring.

\subsection{Computational studies}

Molecular geometries obtained through theoretical methods are useful to explain the structures of compounds. Optimization of all compounds was carried out at the B3LYP/6-31G (d) level of DFT. Optimized geometries of compounds (Figure 1) showed that the acridone ring is not completely planar; it is a little bend of approximately $2.6^{\circ}$ relative to the axis that passes through the nitrogen of the amino group and the keto, and the interplanar angle between the acridone ring and the triazole ring is $47^{\circ}$. On the other hand in both compounds $4 \mathrm{~d}$ and $4 \mathrm{~h}$ bearing an acid group, intramolecular hydrogen bonds are formed between amide hydrogen and the acidic oxygen. For the other compounds, intramolecular hydrogen bonds are formed between the nitrogen of the triazole ring and the amide hydrogen.

3.2a Frontier molecular orbitals (FMOs): The most important orbitals in molecules are the frontier molecular orbitals, which refer to HOMO and LUMO orbitals are the most important factors that affect the bioactivity. ${ }^{31}$ The energy gap $\left(\Delta \mathrm{E}_{\mathrm{gab}}=\mathrm{E}_{\mathrm{LuMO}}-\mathrm{E}_{\text {Hомо }}\right)$ between HOMO and LUMO reflect the chemical activity and kinetic stability. ${ }^{32-36}$ The gap energies, HOMO and LUMO for the novel acridone 1,2,3-triazole derivatives were calculated and their FMOs are displayed in (Table 3) sketched in (Figure 2). The calculated energy gap is almost constant for all the synthesized compounds and the results showed that the substitution has an insignificant effect on the energy gap except for molecules $4 \mathrm{~d}$ and $4 \mathrm{~h}$ that are substituted by an acid group. For these compounds, small decreases in the LUMO levels are observed and lead to stabilization of $4 \mathrm{~d}$ and $4 \mathrm{~h}$. The distributions charges in HOMO orbitals are mainly situated over the acridone ring. In effect, they are not influenced by the nature of the substituent on the triazole rings. Concerning the LUMO orbitals, they are also located over the acridone ring for all studied compounds except $4 \mathrm{~d}$ and $4 \mathrm{~h}$ that are substituted by a carboxylic acid group. LUMO orbitals for compounds $4 \mathrm{~d}$ and $4 \mathrm{~h}$ are located on the benzoic acid unit due to the attractive effect of the acid group. 
Table 2. Scope of target compounds through the reaction of terminal alkynes (1a-b) and 2-azido-N-phenylacetamide (3a-d).

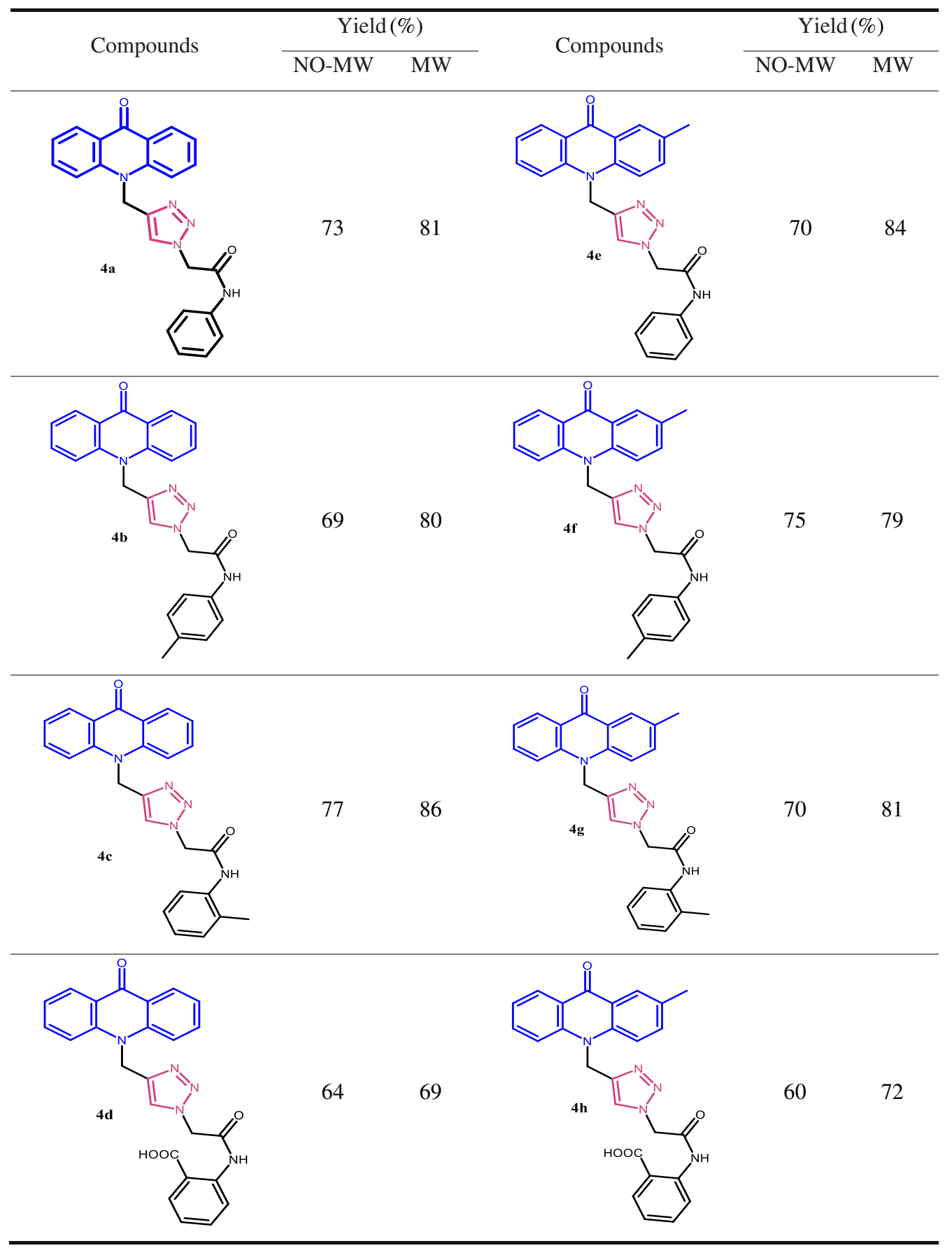

Furthermore, the HOMO and LUMO energy values are used to compute global chemical reactivity descriptors such as chemical hardness $(\eta)$, electrophilicity $(\omega)$ and electronegativity $(X)$ are reported in Table 3 . Chemical hardness is related to the stability and reactivity of a chemical system represented by $\eta=\left(E_{\text {LUMO }}-\right.$ $\left.\mathrm{E}_{\mathrm{HOMO}}\right) / 2$. This parameter is used as a measure of resistance to change in the electron distribution or charge in a molecule. ${ }^{37}$ Electrophilicity index measures the propensity or capacity of a species to accept electrons. ${ }^{38}$ It is a measure of the stabilization in energy after a system accepts an additional amount of electronic charge from the environment. Electronegativity is given by expression $\omega=\mu^{2} / 2 \eta$ and ( $\mu=$ chemical potential). Electronegativity is given by expression $\chi=$ $-\left(\mathrm{E}_{\mathrm{HOMO}}+\mathrm{E}_{\mathrm{LUMO}}\right) / 2$, which is defined as the power of an atom in a molecule to attract electrons towards it. $^{39}$ 

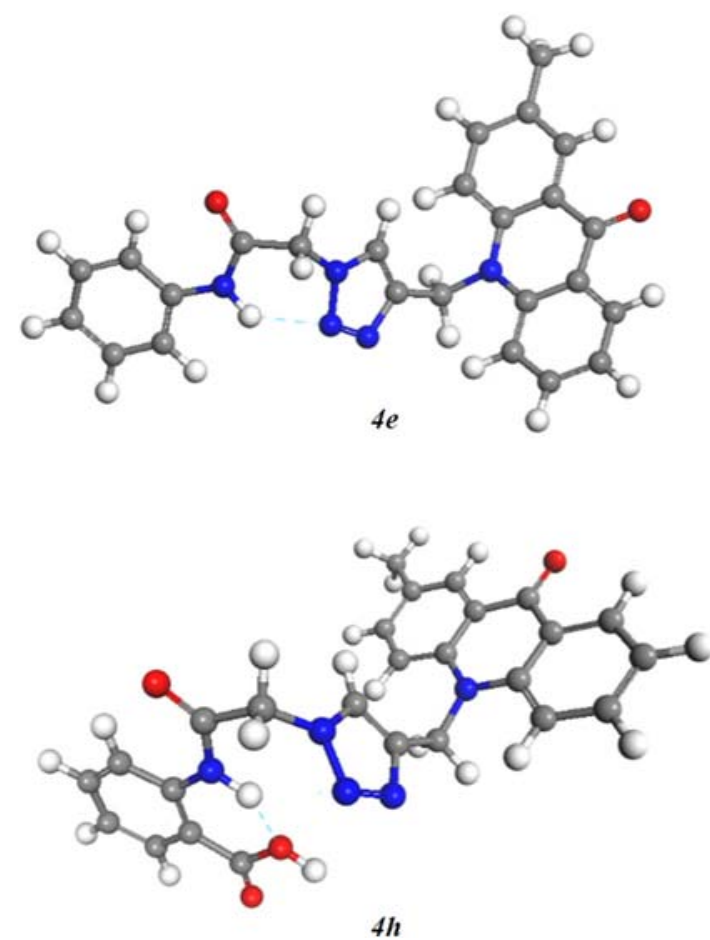
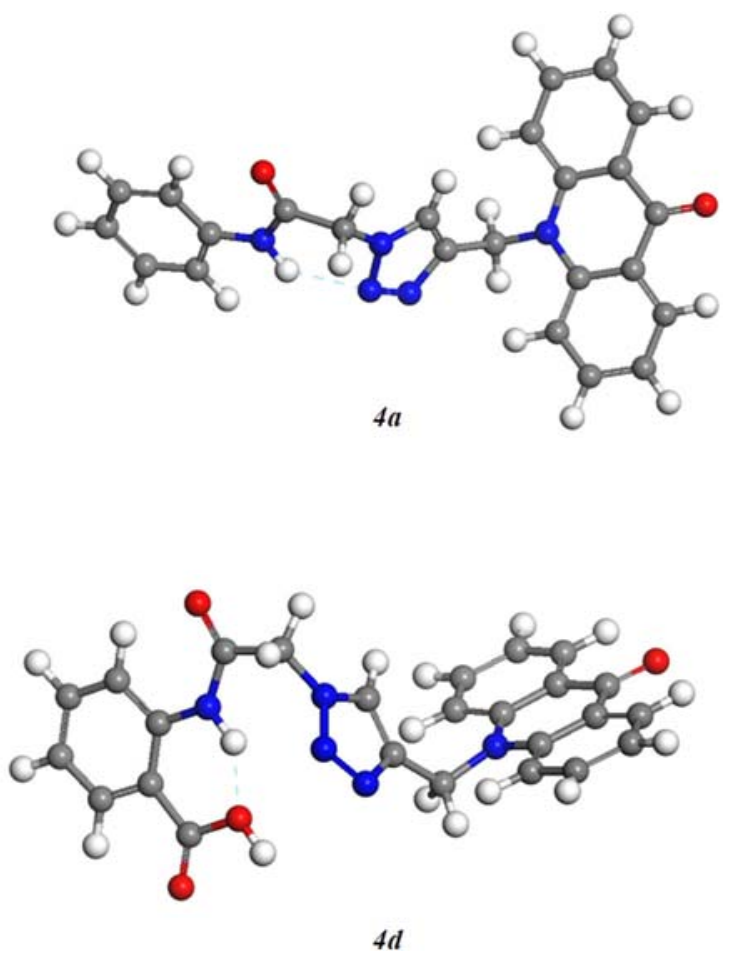

Figure 1. The optimized geometries of $4 \mathrm{a}, 4 \mathrm{~d}, 4 \mathrm{e}$ and $4 \mathrm{~h}$ at the B3LYP/6-31G (d) level of DFT.

Table 3. Quantum chemical parameters of acridone 1,2,3-triazole compounds calculated by B3LYP/6-31G(d) level of theory.

\begin{tabular}{lcccccccc}
\hline & & & & $\begin{array}{c}\text { Chemical } \\
\text { hardness } \\
\text { Compounds }\end{array}$ & $\begin{array}{c}\text { Ehemical } \\
\text { softness } \\
(S)\end{array}$ & $\begin{array}{c}\text { Electro- } \\
\text { negativity } \\
(\chi)\end{array}$ & $\begin{array}{c}\text { Electro- } \\
\text { philicity } \\
(\omega)\end{array}$ & $\begin{array}{c}\text { Lipo- } \\
\text { phylicity } \\
\text { Log }(\mathrm{P})\end{array}$ \\
\hline $\mathbf{4 a}$ & -0.214 & -0.065 & 0.149 & 0.074 & 13.42 & 0.139 & 0.129 & 3.89 \\
$\mathbf{4 b}$ & -0.213 & -0.065 & 0.148 & 0.074 & 13.51 & 0.139 & 0.130 & 4.40 \\
$\mathbf{4 c}$ & -0.214 & -0.065 & 0.149 & 0.074 & 13.42 & 0.139 & 0.129 & 4.40 \\
$\mathbf{4 d}$ & -0.214 & -0.074 & 0.140 & 0.070 & 14.28 & 0.144 & 0.148 & 4.20 \\
$\mathbf{4 e}$ & -0.209 & -0.063 & 0.146 & 0.073 & 13.69 & 0.136 & 0.126 & 4.40 \\
$\mathbf{4 f}$ & -0.209 & -0.063 & 0.146 & 0.073 & 13.69 & 0.136 & 0.126 & 4.92 \\
$\mathbf{4 g}$ & -0.209 & -0.063 & 0.146 & 0.073 & 13.69 & 0.136 & 0.126 & 4.92 \\
$\mathbf{4 h}$ & -0.209 & -0.073 & 0.136 & 0.068 & 14.70 & 0.141 & 0.146 & 4.71 \\
\hline
\end{tabular}

Lipophilicity is defined by the partitioning of a compound between an aqueous and a nonaqueous phase. $\log \mathrm{P}$ is an important physicochemical parameter in the development of lipophilicity index. ${ }^{40,41}$ It is generally accepted that more lipophilic molecule will interact more easily with the fatty acid tails of the lipid bilayer, thus allowing the molecule to cross cell membranes. ${ }^{41}$ As shown in Table 3 the lipophilicity of the synthesized compounds increases with substitution of acridone ring and $\mathrm{N}$-phenylacetamid unit by a methyl group.

3.2b Molecular electrostatic potential surface: The molecular electrostatic potential is related to the electron density and is important to identify the reactive sites of the molecule in electrophilic and nucleophilic. ${ }^{42-44}$ Thus, it allows envisaging centers and their relative reactivity towards electrophilic and nucleophilic attacks. ${ }^{45}$ The molecular electrostatic potential surface was calculated at the B3LYP/6-31G(d) optimized geometry for structures 4a-4h. As showing in (Figure 3), electrophilic sites are red in color which designates the negative regions of the molecule, while the nucleophilic sites are colored in blue and designate the positive regions of the molecule. The molecular electrostatic potential (MEPs) of compounds $4 \mathrm{a}-4 \mathrm{~h}$ shows that the region with the most electronegative potential was located on nitrogen atoms in heteroaromatic 1,2,3 triazole ring and the two oxygen atoms of the carbonyl group of amide and acridone ring. 

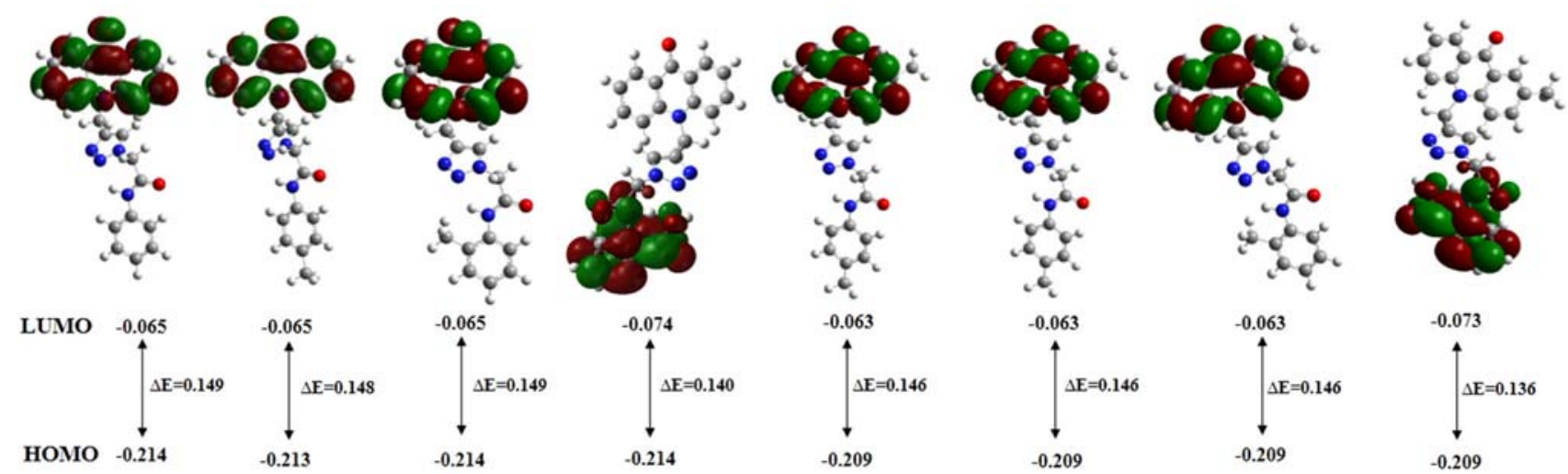

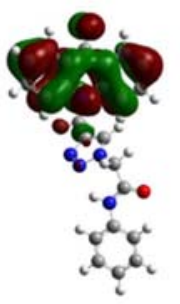

$4 a$

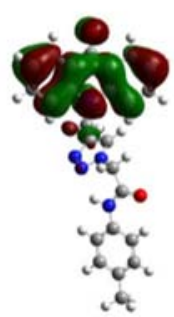

$4 b$

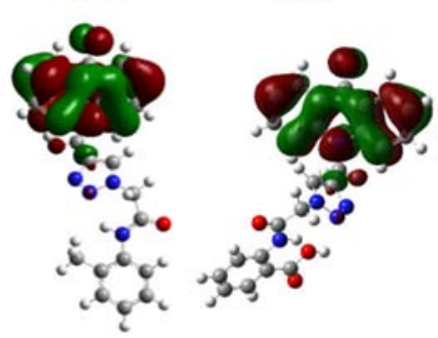

$4 c$

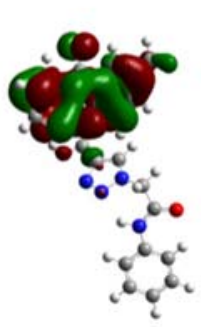

$4 e$

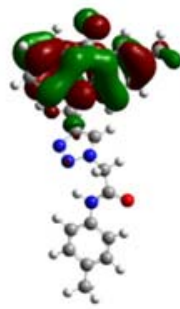

$4 f$

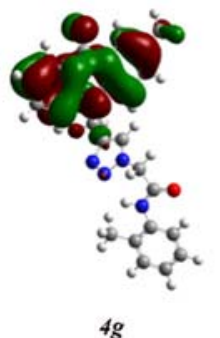

$4 g$

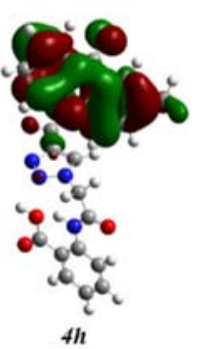

Figure 2. HOMO and LUMO plots of compounds $4 \mathrm{a}-\mathrm{h}$.

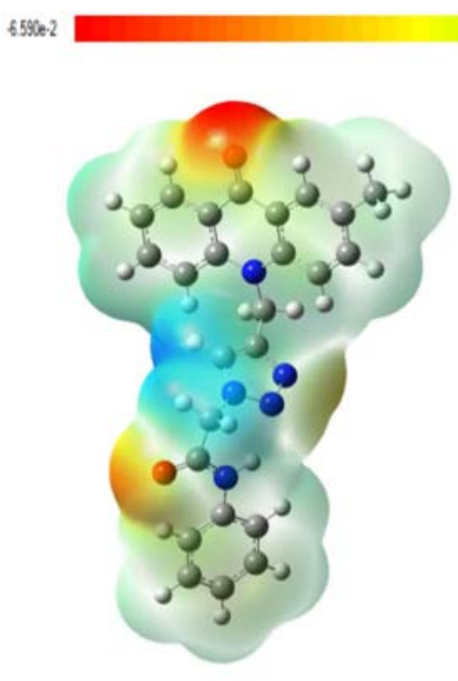

$4 e$

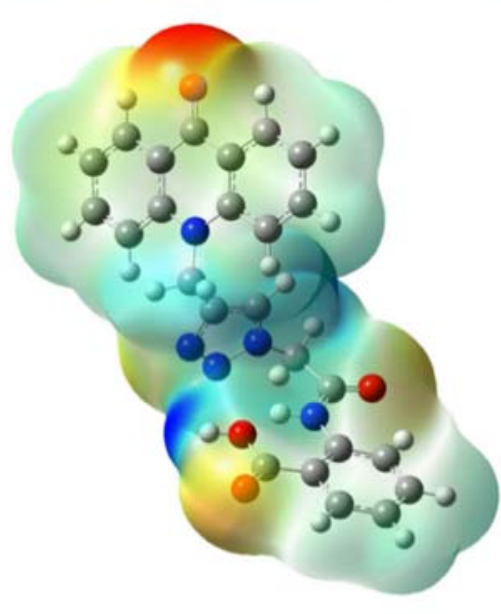

$4 d$

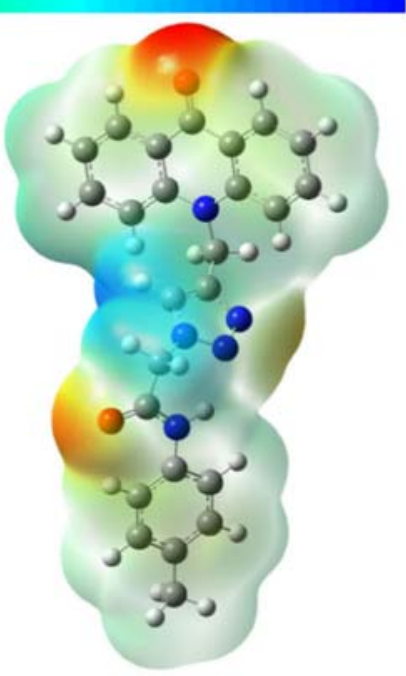

$4 b$

Figure 3. The molecular electrostatic potential surface of molecules 4b, 4d and 4e.

\subsection{Antibacterial activity}

The synthesized compounds were screened in vitro for their antibacterial activities against four gramnegative bacteria Escherichia coli, Klebsiella pneumonia, pseudomonas putida, Serratia marcescens and one gram-positive bacteria Staphyloccocus aureus. Initially, antibacterial activities of synthesized compounds were tested on the basis of the growth inhibition zone utilizing the disc diffusion method under standard conditions using Mueller-Hinton agar medium, according to the Clinical and Laboratory Standards Institute guidelines. ${ }^{46}$ Then the minimum inhibitory concentration (MIC) measurement were conducted to examine the antibacterial activities of the synthesized compounds (4a-h). MIC data showed in Table 4 indicate that compounds $4 \mathrm{c}, 4 \mathrm{e}, 4 \mathrm{f}$ and $4 \mathrm{~g}$ exhibited good inhibitory activities against $S$. aureus $(\mathrm{MIC}=12.3-19.6 \mu \mathrm{g} / \mathrm{mL}$ ) and S. marcescens $(\mathrm{MIC}=43.6-75.2 \mu \mathrm{g} / \mathrm{mL}$ ). Moreover, the compounds $4 \mathrm{e}$ and $4 \mathrm{f}$ showed modest inhibitory 
Table 4. Antibacterial data for the synthesized compounds.

\begin{tabular}{lccccc}
\hline \multirow{2}{*}{ Compounds } & \multicolumn{5}{c}{ Antibacterial activity data in MIC $(\mu \mathrm{g} / \mathrm{ml})$} \\
\cline { 2 - 6 } & S. aureus & E. coli & K. pneumonie & P. putida & S. marcescens \\
\hline $\mathbf{1 a}$ & 122.8 & 133.4 & 137.9 & 156.3 & 129.3 \\
$\mathbf{1 b}$ & 118.4 & 124.2 & 130.4 & 145.5 & 127.3 \\
$\mathbf{4 a}$ & 38.5 & 107.1 & 137.9 & 109.9 & 89.1 \\
$\mathbf{4 b}$ & 28.5 & 74.1 & 86.9 & 90.1 & 66.1 \\
$\mathbf{4 c}$ & 19.6 & 90.6 & 70.4 & 88.8 & 43.6 \\
$\mathbf{4 d}$ & 72.9 & 90.9 & 122.8 & 120.3 & 109.0 \\
$\mathbf{4 e}$ & 19.6 & 65.4 & 74.1 & 77.1 & 75.2 \\
$\mathbf{4 f}$ & 12.3 & 38.5 & 56.6 & 74.9 & 46.3 \\
$\mathbf{4 g}$ & 19.6 & 36.6 & 56.6 & 115.0 & 51.3 \\
$\mathbf{4 h}$ & 38.5 & 56.6 & 107.1 & 121.8 & 20.3 \\
Chloramphenicol & 11.6 & 22.4 & 15.3 & 37.1 & - \\
DMF (control) & - & - & - & - & \\
\hline
\end{tabular}

activity against $P$. putida $(\mathrm{MIC}=74.9 \mu \mathrm{g} / \mathrm{mL}$ ) and the compounds $4 \mathrm{f}$ and $4 \mathrm{~g}$ present $\mathrm{MIC}=56.6 \mu \mathrm{g} / \mathrm{mL}$ against $K$. pneumonia. Noticeably, compound $4 \mathrm{~g}$ was the most potent inhibitor against $E$. coli with a MIC value at $36.6 \mu \mathrm{g} / \mathrm{mL}$. It was found that $4 \mathrm{f}$ was the most potent compound against Gram-positive and Gram-negative organisms, the activity of $4 \mathrm{f}$ was slightly weaker than that of Chloramphenicol against S. aureus (MIC = $12.3 \mu \mathrm{g} / \mathrm{ml})$.

The MIC values listed in Table 4 showed an improvement in antibacterial activity after the substitution of the acridone ring by a triazole ring for all the germs, against the Staphyloccocus aureus the MIC was decreased from 122.8 to $19.6 \mu \mathrm{g} / \mathrm{mL}$. Thus the substitution of acridone at position 2 by a methyl increases the antibacterial efficiency against all the germs. It can be observed that methyl substitution on the benzene ring was favorable to increase the antibacterial activity of the compounds. We can see that the antibacterial activity of the synthesized compounds may be due to the evolvement of the lipophilic character of the molecules, which help the crossing through the biological membrane of the bacteria and thereby inhibit their growth.

\section{Conclusions}

In this work, novel acridone-1,2,3-triazole hybrid derivatives were synthesized by microwave irradiation and conventional methods. The use of the MW method in the copper(I)-catalyzed azide-alkyne cycloaddition (CuAAC) leads us to good yields and short reaction time. Structures of the novel acridon-1,2,3-triazole hybrid derivatives were determined by NMR, FTIR spectroscopy and mass spectrometry. All the synthesized compounds were screened for their in vitro antibacterial activities against Escherichia coli, Klebsiella pneumonia, Pseudomonas putida, Serratia marcescens and Staphyloccocus aureus, indicating that the substitution of the acridone ring by a 1,2,3-triazole nucleus increases the antibacterial potential of our compounds. The best antibacterial effect was exhibited by compound 4 f against $S$. aureus. Theoretical calculations based on DFT were performed to determine the HOMO, LUMO, gap energies and MEPs. Results showed that gap energies are almost similar for all the synthesized compounds and that the substitution has a negligible effect on the gap energies. The molecular electrostatic potential (MEPs) maps show that the negative potential sites are on nitrogen atoms in heteroaromatic 1,2,3 triazole ring and the two oxygen atoms of the carbonyl group of amide and acridone ring.

\section{Supplementary Information (SI)}

The method of determination of minimum inhibitory concentration, quantum chemical calculation, synthesis method, ${ }^{1} \mathrm{HNMR},{ }^{13} \mathrm{CNMR}$ spectra are available at www.ias.ac.in/ chemsci.

\section{References}

1. Dzierzbicka K 2017 Recent developments in the synthesis and biological activity of acridine/acridone analogues RSC Adv. 15776

2. Michel S and Tillequin F 1997 Bioactive natural and synthetic acronycine derivatives modified at the pyran ring Stud. Nat. Prod. Chem. 20789

3. Tillequin F and Koch M 2005 De l'acronycine aux dérivés de la benzo[b]acronycine:conception et développement d'une nouvelle série d'antitumoraux Ann. Pharm. Françaises 6335

4. Nguyen Q C, Nguyen T T, Yougnia R, Gaslonde T, Dufat H, Michel S and Tillequin F 2009 Acronycine 
derivatives: a promising series of anticancer agents, AntiCancer Agents Med. Chem. (Los. Angeles). 9804

5. Belmont $\mathrm{P}$ and Dorange I 2008 Acridine/acridone: a simple scaffold with a wide range of application in oncology Expert Opin. Ther. Pat. 181211

6. Lebegue N, Gallet S, Flouquet N, Carato P, Pfeiffer B, Renard P, Léonce S, Pierré A, Chavatte P and Berthelot P 2005 Novel Benzopyridothiadiazepines as Potential Active Antitumor Agents J. Med. Chem. 487363

7. Cholewinski G, Dzierzbicka K and Kolodziejczyk A M 2011 Natural and synthetic acridines/acridones as antitumor agents: their biological activities and methods of synthesis Pharmacol. Rep. 63305

8. Denny W A 2002 Acridine Derivatives as Chemotherapeutic Agents Curr. Med. Chem. 91655

9. Kukowska-Kaszuba M and Dzierzbicka K 2007 Synthesis and structure-activity studies of peptideacridine/acridone conjugates Curr. Med. Chem. 14 3079

10. Rewcastle G W, Atwell G J, Chambers D, Baguley B C and Denny W A 1986 Potential antitumor agents. 46. Structure-activity relationships for acridine monosubstituted derivatives of the antitumor agent N-[2-(dimethylamino)ethyl]-9-aminoacridine-4carboxamide J. Med. Chem. 29472

11. Phanstiel O IV, Price H L, Wang L, Juusola J, Kline M and Majmundar Shah S 2000 The Effect of Polyamine Homologation on the Transport and Cytotoxicity Properties of Polyamine-(DNA-Intercalator) Conjugates $J$. Org. Chem. 655590

12. Watterson $\mathrm{S} \mathrm{H}$, Chen $\mathrm{P}$, Zhao $\mathrm{Y}, \mathrm{Gu} \mathrm{H} \mathrm{H}$, Dhar T G, Xiao Z, Ballentine S K, Shen Z, Fleener C A, Rouleau K A, Obermeier M, Yang Z, McIntyre K W, Shuster D J, Witmer M, Dambach D, Chao S, Mathur A, Chen B C, Barrish J C, Robl J A, Townsend R and Iwanowicz E J 2007 AcridoneBased Inhibitors of Inosine 5'-Monophosphate Dehydrogenase: Discovery and SAR Leading to the Identification of N-(2-(6-(4-Ethylpiperazin-1-yl)pyridin-3yl)propan-2-yl)-2- fluoro-9-oxo-9,10-dihydroacridine3-carboxamide (BMS-566419) J. Med. Chem. 503730

13. Stankiewicz-Drogon A, Palchykovska L G, Kostina V G, Alexeeva IV, Shved A D and Boguszewska-Chachulska A M 2008 New acridone-4-carboxylic acid derivatives as potential inhibitors of Hepatitis C virus infection Bioorg. Med. Chem. 168846

14. Singh P, Kaur J, Yadav B and Komath S S 2009 Design, synthesis and evaluations of acridone derivatives using Candida albicans - search for MDR modulators led to the identification of an anti-candidiasis agent Bioorg. Med. Chem. 173973

15. Antonini I, Polucci P, Magnano A, Gatto B, Palumbo M, Menta E, Pescalli N and Martelli S 2003 Design, synthesis, and biological properties of new bis(acridine4-carboxamides) as anticancer agents J. Med. Chem. 46 3109

16. Singh N, Pandey S K and Tripathi R P 2010 Regioselective $[3+2]$ cycloaddition of chalcones with a sugar azide: easy access to 1-(5-deoxy-d-xylofuranos-5-yl)-4,5disubstituted-1H-1,2,3-triazoles Carbohydr. Res. 345 1641
17. Farajzadeh M A and Khoshmaram L 2013 Air-assisted liquid-liquid microextraction-gas chromatographyflame ionisation detection: a fast and simple method for the assessment of triazole pesticides residues in surface water, cucumber, tomato and grape juices samples Food Chem. 1411881

18. Lazrek H B, Taourirte M, Oulih T, Barascut J L, Imbach J L, Pannecouque $\mathrm{C}$, Witrouw $\mathrm{M}$ and De Clercq E 2001 Synthesis and anti-HIV activity of new modified 1,2,3-triazole acyclonucleosides Nucleosides Nucleotides Nucleic Acids 201949

19. Demaray J A, Thuener J E, Dawson M N and Sucheck S J 2008 Synthesis of triazole-oxazolidinones via a onepot reaction and evaluation of their antimicrobial activity Bioorg. Med. Chem. Lett. 184868

20. Khan I, Ali S, Hameed S, Rama N H, Hussain M T, Wadood A, Uddin R, Ul-Haq Z, Khan A, Ali S and Choudhary M I 2010 Synthesis, antioxidant activities and urease inhibition of some new 1,2,4-triazole and 1,3,4-thiadiazole derivatives Eur. J. Med. Chem. 45 5200

21. Chen H, Zuo S, Wang X, Tang X, Zhao M, Lu Y, Chen L, Liu J, Liu Y, Liu D, Zhang S and Li T 2011 Synthesis of $4 \beta$-triazole-podophyllotoxin derivatives by azide-alkyne cycloaddition and biological evaluation as potential antitumor agents Eur. J. Med. Chem. 46 4709

22. Sondhi S M, Singh J, Rani R, Gupta P P, Agrawal S K and Saxena A K 2010 Synthesis, anti-inflammatory and anticancer activity evaluation of some novel acridine derivatives Eur. J. Med. Chem. 45555

23. Mohammadi-Khanaposhtani M, Mahdavi M, Saeedi M, Sabourian R, Safavi M, Khanavi M, Foroumadi A, Shafiee A and Akbarzadeh T 2015 Design, synthesis, biological evaluation, and docking study of acetylcholinesterase inhibitors: new acridone-1,2,4oxadiazole-1,2,3-triazole hybrids Chem. Biol. Drug Des. 861425

24. Kolb H C, Finn M G and Sharpless K B 2001 Click chemistry: diverse chemical function from a few good reactions Angew. Chem. Int. Ed. Engl. 402004

25. Rostovtsev V V, Green L G, Fokin V V and Sharpless K B 2002 A stepwise huisgen cycloaddition process: copper(I)-catalyzed regioselective 'ligation' of azides and terminal alkynes Angew. Chem. Int. Ed. Engl. 41 2596

26. Liang L and Astruc D 2011 The copper(I)-catalyzed alkyne-azide cycloaddition (CuAAC) "click" reaction and its applications. An overview Coord. Chem. Rev. 255 2933

27. Kumar D, Reddy V B and Varma R S 2009 A facile and regioselective synthesis of 1,4-disubstituted 1,2,3triazoles using click chemistry Tetrahedron Lett. 50 2065

28. Davies J and Davies D 2010 Origins and evolution of antibiotic resistance Microbiol. Mol. Biol. Rev. 74417

29. Ventola C L 2015 The antibiotic resistance crisis: part 1: causes and threats $P T \mathbf{4 0} 277$

30. Nouraie P, Moradi Dehaghi S and Foroumadi A 2019 Coumarin-1,2,3-triazole hybrid derivatives: green synthesis and DFT calculations Synth. Commun. 1 
31. Liu, X-H 2007 Synthesis, bioactivity, theoretical and molecular docking study of 1-cyano-N-substitutedcyclopropanecarboxamide as ketol-acid reductoisomerase inhibitor Bioorg. Med. Chem. Lett. 17 3784

32. Kosar B and Albayrak C 2011 Spectroscopic investigations and quantum chemical computational study of (E)-4-methoxy-2-[(p-tolylimino)methyl]phenol Spectrochim. Acta Part A 78160

33. Sun Y-X, Hao Q-L, Yu Z-X, Wei W-X, Lu L-D and Wang X 2009 Experimental and density functional studies on 4-(4-cyanobenzylideneamino)antipyrine Mol. Phys. 107 223

34. Reed A E, Weinstock R B and Weinhold F 1985 Natural population analysis J. Chem. Phys. 83735

35. Adant C, Dupuis M and Bredas J L 1995 Ab initio study of the nonlinear optical properties of urea: electron correlation and dispersion effects Int. J. Quantum Chem. 56 497

36. Arivazhagan M and Meenakshi R 2011 Quantum chemical studies on structure of 1-3-dibromo-5-chlorobenzene Spectrochim. Acta Part A 82316

37. Reed J L 1997 Electronegativity: chemical hardness I J. Phys. Chem. 10140

38. Mebi C 2011 DFT study on structure, electronic properties, and reactivity of cis-isomers of $\left[\left(\mathrm{NC}_{5} \mathrm{H}_{4}-\mathrm{S}\right)_{2} \mathrm{Fe}(\mathrm{CO})_{2}\right]$ J. Chem. Sci. 123727

39. Parr R G and Yang W 1984 Density functional approach to the frontier-electron theory of chemical reactivity $J$. Am. Chem. Soc. 1064049

40. Kapustikova I, Bak A, Gonec T, Kos J, Kozik V and Jampilek J 2018 Investigation of Hydro-Lipophilic
Properties of $N$-Alkoxyphenylhydroxynaphthalenecarboxamides Molecules 231635

41. Arnott J A, Kumar R and Planey S L 2013 Lipophilicity indices for drug development J. Appl. Biopharm. Pharmaco. 131

42. Scrocco E and Tomasi J 1978 Electronic molecular structure, reactivity and intermolecular forces: an Euristic interpretation by means of electrostatic molecular potentials Adv. Quantum Chem. 11115

43. Luque F J, López J M and Orozco M 2000 Perspective on "electrostatic interactions of a solute with a continuum. A direct utilization of ab initio molecular potentials for the prevision of solvent effects" In Theoretical Chemistry Accounts C J Cramer and D G Truhlar (Eds.) (Berlin, Heidelberg: Springer)

44. Parthasarathi R, Padmanabhan J, Sarkar U, Maiti B, Subramanian V and Chattaraj P K 2003 Toxicity analysis of benzidine through chemical reactivity and selectivity profiles: a DFT approach Internet Electron. J. Mol. Des. 2789

45. Avdović E H, Milenković D, Marković J M D, Dorović J, Vuković N, Vukić M D, Jevtić V V, Trifunović S R, Potočňák I and Marković Z 2018 Synthesis, spectroscopic characterization (FT-IR, FT-Raman, and NMR), quantum chemical studies and molecular docking of 3(1-(phenylamino)ethylidene)-chroman-2,4-dione Spectrochim. Acta Part A 19531

46. CLSI. Performance Standards for Antimicrobial Disk Susceptibility Tests; Approved Standard - Twelfth Edition. CLSI document M02-A12. Wayne, PA: Clinical Laboratory Standard Institute; 2015. ISBN 1-56238986-6 